\title{
Impact of covid-19 pandemic: Perception of clinical year medical students on transition of traditional to online lectures in a medical university of Karachi, Pakistan.
}

\section{MBBS, MCPS \\ Senior Registrar Pediatrics BUMDC. \\ 2. MBBS, FCPS \\ Senior Registrar Pediatrics BUMDC.}

Correspondence Address: Dr. Shazia Fakhir

Department of Pediatrics BUMDC.

shaziafakhir@hotmail.com

Article received on:

10/08/2020

Accepted for publication: 06/10/2020

\begin{abstract}
Shazia Durrani Fakhir ${ }^{1}$, Ammara Hameed ${ }^{2}$
ABSTRACT... Objective: To determine the perception of clinical undergraduate MBBS students of online lectures in a medical university of Karachi, Pakistan. Study Design: Descriptive Study. Setting: Bahria University Medical and Dental College. Period: May 2020 till July 2020. Material \& Methods: Four weeks after introduction of online lectures. Data was collected from clinical year students over two weeks using Google forms and analysed using SPSS version 22. Result: Of 450 clinical year students, $n=234$ responded. Overall, $48.7 \%(n=114)$ students were satisfied with the online lectures, $34.2 \%(n=80)$ were completely satisfied and 17.7 $\%(n=39)$ were unsatisfied. $53.4 \%(n=125)$ felt lectures were serving the purpose whereas $37.2 \%(n=87)$ do not feel the same. The lack of interaction component in online lectures was felt by $45.7 \%(n=107)$ students. Regarding clinical teaching, $72.2 \%(n=170)$ do not think it is possible online, $15.8(n=35)$ feel it possible and $12.4 \%(n=29)$ were hopeful. Majority $61.1 \%(n=143)$ think it is impossible to complete medical studies online. Student ideas for improvement included availability of lecture recording for later viewing, integrated quizzes, increasing interactive component, training of faculty, small group sessions and case based teaching. Majorly students faced internet connectivity issues and timings of long lectures without break. Conclusion: Online lectures can be improved by reducing the issues faced by students, providing them easy internet access, faculty training programs to make interactive and case based presentation and quizzes.
\end{abstract}

Key words: Online Lectures, e Learning, Medical Students, Student Perception.

Article Citation: Fakhir SD, Hameed A. Impact of covid-19 pandemic: Perception of clinical year medical students on transition of traditional to online lectures in a medical university of Karachi, Pakistan. Professional Med J 2021; 28(5):625629. https://doi.org/10.29309/TPMJ/2021.28.05.5970

\section{INTRODUCTION}

Covid pandemic has had a significant impact on medical education. Especially difficult is for the medical students who have to learn through online lectures alone and make the most of the situation. Previously students were having early morning traditional classroom large group lectures followed by clinical sessions in hospital wards and clinical hands on examination and history taking skills were taught, practiced and real patient scenarios observed and discussed in smaller groups. Unfortunately only online lecture have been made possible as yet since the closure of all teaching hospitals for students. This particular way in which online lectures are being conducted in place of traditional classes is relatively new and needs to be further researched to improve and facilitate learning. ${ }^{1}$
The concept of online classes is perceived differently by the students. ${ }^{2}$ We need to assess the way online classes are perceived so that improvement methods are introduced to achieve maximum learning. ${ }^{3}$ Student perception was studied since quite a while and gave positive results. ${ }^{4} \mathrm{~A}$ study showed that more students showed improvement learning through online sessions than face to face teaching. ${ }^{5}$ Another study showed that undergraduate medical students showed better reception of online lectures and resulted in overall improved outcomes. ${ }^{6}$ Similar results in seen in dental students $^{7} \mathrm{E}$ learning in Korean medical colleges was studied and showed satisfactory results. ${ }^{8,9}$ Significant evidence in the learning skills reveals the emphases of participation in online learning environments. ${ }^{10}$ Medical students have 
generally expressed strong satisfaction with early applications of online classes to undergraduate medical education. ${ }^{11}$ More study has been done internationally and nationally to study the student perspective and to assess online learning and use of internet facilities. ${ }^{12,13,14}$ Few more studied showed results on online learning where student perception was recorded specially the advantages, disadvantages and also the barriers to learning online. ${ }^{15,16}$

\section{MATERIAL \& METHODS}

Place and duration of study was Bahria University Medical and Dental College started from May 2020 till July 2020. Study type was Descriptive study type with a purposive sampling technique. Inclusion criteria was All MBBS students clinical years including third, fourth and final year student taking online classes and Exclusion criteria included students who do not have access to online classes and preclinical MBBS years Study Instrument used was Google online questionnaire.

Procedure in Details that The questionnaire was made online google forms and consists of 3 sections including declared and informed written consent, personal information and third consists of the data collection regarding student perception questions. Names to remain anonymous. Only clinical years MBBS classes were included in the data collection survey. 7 questions are quantitative and one is open ended question where students give their opinion regarding their perception and ideas for improvement. Out of total 450 students in theses clinical years in Bahria university medical college, according to open Epi, the sample size comes to be 208. 234 responses were however recorded. Analysis done on spss version 22.

\section{RESULT}

MBBS classes of third, fourth and final year taking online lectures during lockdown were asked their perception on this type of online classes taking place in their institute Out of 450, 234 responded. Seven items were assessed on a 3-point response scale. Table-I shows the distribution frequency of responses to the seven assessed components.

An open ended question was used to take input of student ideas for improvement in the online lecture format. Figure-1 shows six themes identified by students and their frequency by clinical year.

Students were also asked about the major issues faced by them in adapting to the online teaching. Internet connectivity issues was identified by $13.1 \%(n=32)$ students and timings of long lectures without break was a problem for $4.5 \%$ $(n=11)$.

\section{DISCUSSION AND ANALYSIS}

Online classes and courses have been taking place in virtual institutes since some time. ${ }^{17}$ This is the first time during this pandemic that medical college has to take online lectures even for clinical MBBS regular students ${ }^{18}$ Student perception is important to know what they expect out of these lectures and any problem they face. Student perception is significantly related to their overall satisfaction of the online classes. ${ }^{19}$

\section{STUDENT PERCEPTION FOR ONLINE LECTURES}

\begin{tabular}{|l|c|c|c|}
\hline \multicolumn{1}{|c|}{ Assessed Item } & Yes n (\%) & Somewhat n (\%) & No n (\%) \\
\hline Are you satisfied with online lectures? & $80(34.2)$ & $114(48.7)$ & $39(17.7)$ \\
\hline Do online lectures serve the purpose? & $125(53.3)$ & $62(26.5)$ & $47(20.1)$ \\
\hline Are online lectures good substitute for traditional lectures? & $78(33.3)$ & $67(28.3)$ & $87(37.2)$ \\
\hline Did online lectures improve learning? & $82(34.9)$ & $60(25.6)$ & $92(39.2)$ \\
\hline Are interactive lectures possible online? & $44(18.8)$ & $83(35.4)$ & $107(45.7)$ \\
\hline Are clinical sessions possible online? & $35(15.8)$ & $29(12.4)$ & $170(72.2)$ \\
\hline Are Medical studies possible online? & $52(18.4)$ & $48(20.4)$ & $143(61.1)$ \\
\hline
\end{tabular}

Table-I. Frequency of responses as $n(\%)$; total responder $n=234$ 
Student Suggestions for improvement of online lectures

case based lectures

small grouos

interactive

faculty training

quizes

recording of lectures

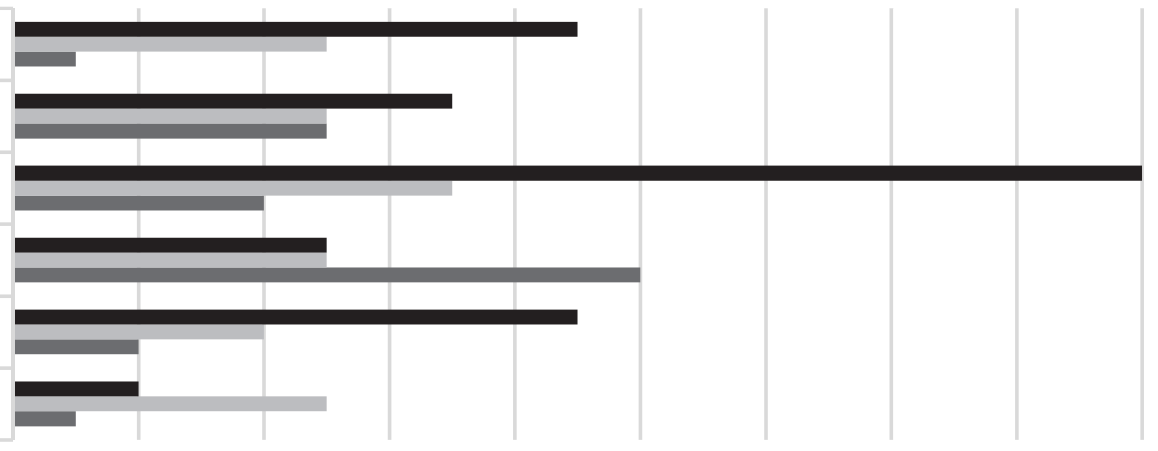

\begin{tabular}{|c|c|c|c|c|c|c|}
\hline & 0 & 4 & 6 & 12 & 14 & 18 \\
\hline & $\begin{array}{l}\text { recording of } \\
\text { lectures }\end{array}$ & quizes & $\begin{array}{l}\text { faculty } \\
\text { training }\end{array}$ & interactive & $\begin{array}{l}\text { small } \\
\text { grouos }\end{array}$ & $\begin{array}{c}\text { case based } \\
\text { lectures }\end{array}$ \\
\hline final year & 2 & 9 & 5 & 18 & 7 & 9 \\
\hline fourth year & 5 & 4 & 5 & 7 & 5 & 5 \\
\hline third year & 1 & 2 & 10 & 4 & 5 & 1 \\
\hline
\end{tabular}

final year $\square$ fourth year $\square$ third year

Almost half of the student were generally satisfied with the ongoing online lectures as they believed these lectures kept them in touch with their studies and faculty as well as their peers. Few said studies would be better if colleges opened.

Online learning may not be applicable for every medical student. Every student has different learning styles and needs to be analyzed. Some learn visually others by repeating and reviewing the lectures. By asking student their needs, measures can be taken to improve student performance as well as satisfaction. ${ }^{20}$ More than half of the students believed online lectures were serving the purpose for which they were started since they were necessary to continue education while institutes could not open and complete the syllabus despite this unusual situation.

There was a mixed reaction for the question that online lectures could actually replace traditional classroom lectures and infact some thought they were even better as traditional classes with such a large group did not allow back benchers to get maximum benefit and also hearing and attention was compromised..$^{21}$ Some student do feel online lectures have kept them updated and also help improve their learning as lifelong adult learning is self-directed and not faculty centered.

When inquired whether online interactive sessions are possible, only a few said yes, because most of the faculty was simply uploading recorded lectures which made interaction impossible. Those taking live lectures were not making any or minimum interactions. A large group also makes interaction less likely and all students are unable to interact. Smaller groups would make interaction possible. Students do not think it would be possible to have clinical sessions online. Few did believe it was possible as virtual learning through virtual simulators has been in use for medical for some time. Majority of the students still feel medical studies are not possible online and nothing could replace actual patient contact and examination.

The use of Computer for medical teaching and learning is anticipatable to increase. Medical educators are already beginning to introduce 
computer based classes. They have the benefit of being convenient and flexible. Each student can study at his or her speed. Weaker students would be at particular benefit as they can stop the lecture, repeat and restart at their own pace. ${ }^{22}$

A study done in India recently showed student satisfaction for online classes and they felt it was a good diversion from stressing about the present COVID situation and they could organize their learning according to their own pace and also improve their mental health. ${ }^{23}$ Another study states that after this pandemic is over everyone will be having their own story to tell, medical students in particular feel it has impacted their education on a different level altogether. ${ }^{24}$

\section{LIMITATIONS}

Single institute students have been included.

\section{CONCLUSION}

Online learning can be improved by removing the issues faced by students, providing them easy internet access and developing faculty training programs for better use of technology as well as how to make interactive and case based presentation that give maximum learning environment to clinical students like online videos and practical implications and critical thinking quizzes.

\section{ACKNOWLEDGEMENT}

I wish to express my deepest gratitude to the academic head of departments of the Paediatric ward, my institute for encouraging and facilitating a research environment and my colleagues. Special thanks to my friends and family who encouraged and motivated me to complete my manuscript.

Copyright@ 06 Oct, 2020.

\section{REFERENCES}

1. Lao T, Gonzales C. Understanding online learning through a qualitative description of professors and students' experiences. Journal of Technology and Teacher Education. 2005 Jul; 13(3):459-74.

2. Al-Asfour A. Examining student satisfaction of online statistics courses. Journal of College Teaching \& Learning (TLC). 2012 Jan 3;9(1):33-8.
3. Wiecha JM, Vanderschmidt H, Schilling K. HEAL: an instructional design model applied to an online clerkship in family medicine. Academic medicine: journal of the Association of American Medical Colleges. 2002 Sep 1;77(9):925-6.

4. Almaghaslah D, Ghazwani M, Alsayari A, Khaled A. Pharmacy students' perceptions towards online learning in a Saudi Pharmacy School. Saudi pharmaceutical journal. 2018 Jul 1;26(5):617-21.

5. Wiecha JM, Chetty VK, Pollard T, Shaw PF. Webbased versus face-to-face learning of diabetes management: the results of a comparative trial of educational methods. FAMILY MEDICINE-KANSAS CITY. 2006 Oct 1;38(9):647.

6. Tang B, Coret A, Qureshi A, Barron H, Ayala AP, Law $M$. Online lectures in undergraduate medical education: scoping review. JMIR medical education. 2018;4(1):e11.

7. Asiry MA. Dental students' perceptions of an online learning. (2017) Saudi Dent J. 2017; 29(4):167-170.

8. Kim KJ, Kim G. (2019) Development of e-learning in medical education: 10 years' experience of Korean medical schools. Korean J Med Educ. 2019; 31(3):205214. doi:10.3946/kjme.2019.131.

9. Jamil NA, Shaikh S, Munir S, Malek S, Khan A. (2019) Development of e-learning in medical education: A student's perspective. Korean J Med Educ. 2019; 31(4):371-373.

10. Berman NB, Artino AR. Development and initial validation of an online engagement metric using virtual patients. BMC medical education. 2018 Dec;18(1):1-8.

11. Ramnanan CJ, Pound LD. Advances in medical education and practice: student perceptions of the flipped classroom. Advances in medical education and practice. 2017;8:63.

12. Kokoç $M$, Ilgaz $H$, Altun A. Individual cognitive differences and student engagement in video lectures and e-learning environments. InHandbook of research on fostering student engagement with instructional technology in higher education 2020 (pp. 78-93). IGI Global.

13. Cole AW, Lennon L, Weber NL. Student perceptions of online active learning practices and online learning climate predict online course engagement. Interactive Learning Environments. 2019 May 21:1-5. 
14. Latif MZ, Hussain I, Saeed R, Qureshi MA, Maqsood $U$. (2019) Use of smart phones and social media in medical education: Trends, advantages, challenges and barriers. Acta Inform Med. 2019; 27(2):133-138.

15. Hemlata Chari, Margaret Haughey. (2006) The introduction of online learning: A case study of YCMOU. Distance Education 27:1, pages 87-104.

16. Palmer SR, Holt DM. Examining student satisfaction with wholly online learning. Journal of computer assisted learning. 2009 Apr;25(2):101-13.

17. Jin Z. Organizational innovation and virtual institutes. Journal of Knowledge Management. 1999 Mar 1.pp. 7583.

18. O'Doherty D, Dromey M, Lougheed J, Hannigan A, Last J, McGrath D. Barriers and solutions to online learning in medical education-an integrative review. BMC medical education. 2018 Dec;18(1):1-1.

19. Lee SJ, Srinivasan S, Trail T, Lewis D, Lopez S. Examining the relationship among student perception of support, course satisfaction, and learning outcomes in online learning. The Internet and Higher Education. 2011 Jul 1;14(3):158-63.
20. Kauffman H. A review of predictive factors of student success in and satisfaction with online learning. Research in Learning Technology. 2015 Aug 27;23.

21. Moazami F, Bahrampour E, Azar MR, Jahedi F, Moattari M. Comparing two methods of education (virtual versus traditional) on learning of Iranian dental students: a post-test only design study. BMC medical education. 2014 Dec;14(1):1-5.

22. Greenhalgh T. Computer assisted learning in undergraduate medical education. Bmj. 2001 Jan 6;322(7277):40-4.

23. Agarwal S, Kaushik JS. Student's perception of online learning during COVID pandemic. The Indian Journal of Pediatrics. $2020 \mathrm{Jul} ; 87: 554-$.

24. Ferrel MN, Ryan JJ. The impact of COVID-19 on medical education. Cureus. 2020 Mar;12(3).

\section{AUTHORSHIP AND CONTRIBUTION DECLARATION}

\begin{tabular}{|c|l|l|}
\hline Sr. \# & Author(s) Full Name & \multicolumn{1}{|c|}{ Contribution to the paper } \\
\hline 1 & $\begin{array}{l}\text { Shazia Durrani } \\
\text { Fakhir }\end{array}$ & $\begin{array}{l}\text { Conceiving the idea, synopsis } \\
\text { Writing, data collection, analysis of } \\
\text { result and interpretation, manuscript } \\
\text { writing, review and final approval. } \\
\text { Conceiving the idea synopsis } \\
\text { writing, data collection, analysis of } \\
\text { result and interpretation, manuscript } \\
\text { writing, review and final approval. }\end{array}$ \\
\hline 2 & Ammara Hameed \\
\hline
\end{tabular}

